\title{
Uprootedness and the protection of migrants in the International Law of Human Rights
}

\author{
Desarraigamento e a proteção dos migrantes no Direito \\ Internacional dos Direitos Humanos
}

ANTÔNIO AUGUSTO CANÇADO TRINDADE*

Rev. Bras. Polít. Int. 51 (1): 137-168 [2008]

\section{Preliminary Observations}

May I at first express a firm warning against the negative effects of the fact that, in a "globalized" world - the new euphemism en vogue, - frontiers are opened to capitals, goods and services, but regrettably not to human beings. National economies are opened to speculative capitals, at the same time that the labour conquests of the last decades erode. Increasing segments of the population appear marginalized and excluded from material "progress". Lessons from the past seem forgotten, the sufferings of previous generations appear to have been in vain. The current state of affairs appears devoid of a historical sense. To this de-historization of the lifetime are added the idolatry of the market, reducing human beings to mere agents of economic production (ironically, amidst growing unemployment in distinct latitudes).

As a result of this new contemporary tragedy - essentially a man-made one, - perfectly avoidable if human solidarity were to have primacy over individual egoism, there emerges and intensifies the new phenomenon of massive flows of forced migration, - of millions of human beings seeking to escape no longer from individualized political persecution, but rather from hunger and misery, and armed conflicts, - with grave consequences and implications for the application of the international norms of protection of the human person. One decade ago, in a study I prepared for the Inter-American Institute of Human Rights (in Costa Rica, in 1998), published in 2001 in Guatemala, I propounded a human rights approach for the phenomenon of forced migratory fluxes, - distinctly from the classic studies on the subject (pursuant to a strictly historical, or else economic, approach), - and with attention

\footnotetext{
* Professor of International Law at the University of Brasília - UnB, Member of the Institut de Droit International and Former President of the Inter-American Court of Human Rights (aacancadotrindade@yahoo.com.br).
} 
focused on human beings experiencing great vulnerability ${ }^{1}$. On the occasion, I saw it fit to warn that:

"The advances [in this domain] will only be achieved by means of a radical change of mentality. In any scale of values, considerations of a humanitarian order ought to prevail over those of an economic or financial order, over the alleged protectionism of the market of work and over group rivalries. There is, definitively, pressing need to situate the human being in the place that corresponds to him, certainly above capitals, goods and services. This is perhaps the major challenge of the "globalized" world in which we live, from the perspective of human rights"2.

In this article, I shall retake the subject, which has become a topical one, with the purpose of identifying and gathering the elements, accumulated in recent years, that would allow to advance further the aforementioned new approach, proper to human rights, to the consideration of the contemporary phenomenon of forced migrations. To this end, I shall seek to portray the drama of uprootedness and the growing need of protection of migrants, and to identify the basic principles applicable in this new domain of protection of the human person; and shall review the growing international case-law on the matter (of both the European and the Inter-American Courts of Human Rights, as well as other initiatives of protection at the United Nations and regional levels, the implications of the whole issue for the responsibility of States, and its importance for the international community as a whole. The path will then be opened for the presentation of my final reflections on the matter.

\section{The Drama of Uprootedness and the Growing Need of Protection of Migrants}

It has been rightly warned that humankind can only achieve true progress when it moves forward in the sense of human emancipation ${ }^{3}$. It is never to be forgotten that the State was originally conceived for the realization of the common good $^{4}$. No State can consider itself to be above the Law, the norms of which have as ultimate addressees the human beings; in sum, the State exists for the human being, and not vice versa.

1 A.A. Cançado Trindade, Elementos para un Enfoque de Derechos Humanos del Fenómeno de los Flujos Migratorios Forzados (Study of July 1998 prepared for the IIHR), Guatemala City, OIM/IIDH, Sept. 2001, pp. 1-57.

2 Ibid., p. 26.

3 J. Maritain, Los Derechos del Hombre y la Ley Natural, Buenos Aires, Ed. Leviatán, 1982 (reimpr.), pp. 12, 18, 38, 43, 50, 94-96 and 105-108. To J. Maritain, "the human person transcends the State", for having "a destiny superior to time"; ibid., pp. 81-82. On the "human ends of power", cf. Ch. de Visscher, Théories et réalités en Droit international public, 4th. rev. ed., Paris, Pédone, 1970, pp. 18-32 et seq.

4 By State it is here meant the State in a democratic society, that is, the State which respects and ensures respect for human rights, is turned to the common good, and the public powers of which, separated, abide by the Constitution and the rule of law, with effective procedural guarantees of human rights and fundamental freedoms. 
Paradoxically, the expansion of "globalization" has been accompanied pari passu by the erosion of the capacity of the States to protect the economic, social and cultural rights of the persons under their jurisdictions; hence the growing needs of protection of refugees, displaced persons and migrants, in this first decade of the XXIst. century, - what requires solidarity at universal scale ${ }^{5}$. This great paradox appears rather tragic, bearing in mind the considerable advances in science and technology in the last decades, which, nevertheless, have not been able to reduce or erradicate human egoism ${ }^{6}$.

Tragically, the material progress of some has been accompanied by the closing of frontiers to human beings and the appearance of new and cruel forms of human servitude (clandestine traffic of persons, forced prostitution, labour exploitation, among others), of which undocumented migrants are often victims ${ }^{7}$. The increasing controls and current hardships imposed upon migrants have led some to behold and characterize a contemporary situation of "crisis" of the right of asylum ${ }^{8}$.

Migrations and forced displacements, increased and intensified from the nineties onwards ${ }^{9}$, have been characterized particularly by the disparities in the conditions of life between the country of origin and that of destination of migrants. Their causes are multiple, namely: economic collapse and unemployment, collapse in public services (education, health, among others), natural disasters, armed conflicts generating fluxes of refugees and displaced persons, repression and persecution, systematic violations of human rights, ethnic rivalries and xenophobia, violence of distinct forms ${ }^{10}$. In recent years, the so-called "flexibility" in labour

5 S. Ogata, Challenges of Refugee Protection (Statement at the University of Havana, 11.05.2000), Havana/Cuba, UNHCR, 2000, pp. 7-9 (internal circulation); S. Ogata, Los Retos de la Protección de los Refugiados (Statement at the Ministry of External Relations of Mexico, 29.07.1999), Mexico City, UNHCR, 1999, p. 11 (internal circulation). - It has recently been pointed out that early warning systems (originally devised and used in the domain of International Refugee Law) has disclosed some shortcomings, used at times as they have been, simply to coerce people under stress not to migrate; S. Schmeidl, "The Early Warning of Forced Migration: State or Human Security?", in Refugees and Forced Displacement - International Security, Human Vulnerability, and the State (eds. E. Newman and J. van Selm), Tokyo, United Nations University, 2003, pp. 140, 145 and 149-151. From the perspective of the international civil society as a whole, the argument has been propounded in favour of securing full and effective citizenship to law-abiding migrants; M. Frost, "Thinking Ethically about Refugees: A Case for the Transformation of Global Governance", in ibid., pp. 128-129.

6 On the need of "revaluing" what is human and humanitarian nowadays, cf. J.A. Carrillo Salcedo, "El Derecho Internacional ante un Nuevo Siglo", 48 Boletim da Faculdade de Direito da Universidade de Coimbra (1999-2000) p. 257 , and cf. p. 260.

7 M. Lengellé-Tardy, L'esclavage moderne, Paris, PUF, 1999, pp. 26, 77 and 116, and cf. pp. 97-98.

8 Ph. Ségur, La crise du droit d'asile, Paris, PUF, 1998, pp. 110-114, 117, 140 and 155; F. Crépeau, Droit d'asile - De l'hospitalité aux contrôles migratoires, Bruxelles, Bruylant/Éd. Université de Bruxelles, 1995, pp. 306-313 and 337-339.

9 Cf. UNHCR, The State of the World's Refugees - Fifty Years of Humanitarian Action, Oxford, UNHCR/Oxford University Press, 2000, p. 9.

10 N. Van Hear, New Diasporas - The Mass Exodus, Dispersal and Regrouping of Migrant Communities, London, UCL Press, 1998, pp. 19-20, 29, 109-110, 141, 143 and 151; F.M. Deng, Protecting the Dispossessed-A Challenge for the International Community, Washington D.C., Brookings Institution, 1993, pp. 3-20. And cf. also, e.g., H. Domenach and M. Picouet, Les migrations, Paris, PUF, 1995, pp. 42-126. 
relations, amidst the "globalization" of the economy, has also generated mobility, accompanied by personal insecurity and a growing fear of unemployment ${ }^{11}$.

Migrations and forced displacements, with the consequent uprootedness of so many human beings, bring about traumas. Testimonies of migrants give account of the sufferings of the abandonment of home, at times with family separation or disaggregation, of loss of property and personal belongings, of arbitrarinesses and humiliations on the part of frontier authorities and security agents, generating a permanent feeling of injustice ${ }^{12}$. As Simone Weil warned already in the midXXth century, "To be rooted is perhaps the most important and least recognized need of the human soul. It is one of the hardest to define"13.

At the same time and in the same line of thinking, Hannah Arendt warned for the sufferings of the uprooted (the loss of home and of the familiarity of dayto-day life, the loss of profession and of the feeling of usefulness to the others, the loss of the mother tongue as spontaneous expression of feelings), as well as the illusion to try to forget the past ${ }^{14}$. Also in this line of reasoning, in his book Le retour du tragique (1967), J.-M. Domenach observed that one can hardly deny the roots of the human spirit itself, since the very form of aquisition of knowledge on the part of each human being, - and consequently his way of seeing the world, - is to a large extent conditioned by factors such as the place of birth, the mother tongue, the cults, the family and the culture ${ }^{15}$.

In his novel Le temps des déracinés (2003), Elie Wiesel ${ }^{16}$ remarked the former refugees continue somehow to be refugees for the rest of their lives; they escape from one exile to project themselves into another, everything looking provisional, and without feeling at home anywhere. They always keep on remembering where they originally come from ${ }^{17}$, cultivating their memories as a means of defending themselves of their adverse condition of uprooted persons. But the "celebration of

11 N. Van Hear, op. cit. supra n. (10), pp. 251-252. As it has been pointed out, "the ubiquity of migration is a result of the success of capitalism in fostering the penetration of commoditization into far-flung peripheral societies and undermining the capacity of these societies to sustain themselves. Insofar as this 'success' will continue, so too will migrants continue to wash up on the shores of capitalism's core”; ibid., p. 260. Cf. also R. Bergalli (coord.), Flujos Migratorios y Su (Des) control, Barcelona, OSPDH/Anthropos Edit., 2006, pp. 138, 152 and $244-$ 248. - For a study of cased, cf., e.g., M. Greenwood Arroyo and R. Ruiz Oporta, Migrantes Irregulares, Estrategias de Sobrevivencia y Derechos Humanos: Un Estudio de Casos, San José of Costa Rica, IIHR, 1995, pp. 9-159. 12 Ibid., p. 152.

13 Simone Weil, The Need for Roots, London/N.Y., Routledge, 1952 (reprint 1995), p. 41. - On the contemporary drama of uprootedness, cf. A.A. Cançado Trindade, "Reflexiones sobre el Desarraigo como Problema de Derechos Humanos Frente a la Conciencia Jurídica Universal”, in La Nueva Dimensión de las Necesidades de Protección del Ser Humano en el Inicio del Siglo XXI (eds. A.A. Cançado Trindade and J. Ruiz de Santiago), 4th. rev. ed., San José of Costa Rica, UNHCR, 2006, pp. 33-92.

14 Hannah Arendt, La tradition cachée, Paris, Ch. Bourgois Ed., 1987 (orig. ed. 1946), pp. 58-59 and 125-127. And cf. also, on the matter, e.g., C. Bordes-Benayoun and D. Schnapper, Diasporas et nations, Paris, O. Jacob Ed., 2006, pp. 7, 11-12, 45-46, 63-65, 68-69, 129 and 216-219.

15 J.-M. Domenach, Le retour du tragique, Paris, Éd. Seuil, 1967, p. 285.

16 Nobel Peace Prize in 1986, who himself suffered the drama of uprootedness.

17 E. Wiesel, O Tempo dos Desenraizados (Le temps des déracinés, 2003), Rio de Janeiro, Edit. Record, 2004, pp. 18-19. 
memory" has also its limitations, as the uprooted are deprived of horizons, and of the sense of belonging to somewhere ${ }^{18}$. They always need help from others. The drama of the victimized seems to be overlooked and forgotten as time passes by, and the uprooted end up by having to learn to live with the slow and ineluctable diminution even of their own memories ${ }^{19}$.

In my Separate Opinion in the case of the Moiwana Community versus Suriname before the Inter-American Court of Human Rights (Judgment of 06.15.2005), I dwelt upon precisely the projection of human suffering in time of the migrants of that Community (some of whom had fled to French Guyana) who survived a massacre (perpetrated on 11.29.1986 in the N'djuka Maroon village of Moiwana, in Suriname). I charaterized the harm they suffered as

a spiritual one. Under their culture, they remain still tormented by the circumstances of the violent deaths of their beloved ones, and the fact that the deceased did not have a proper burial. This privation, generating spiritual suffering, has lasted for almost twenty years, from the moment of the perpetration of the 1986 massacre engaging the responsibility of the State until now. The N'djukas have not forgotten their dead (par. 29).

Only with the aforementioned Judgment of 2005, almost two decades later, they at last found redress, with the judicial recognition of their suffering and the reparations ordered. In the framework of these latter stands the securing by the State of their voluntary and safe return to their native lands ${ }^{20}$. This was not the first time that I addressed the issue of the projection of human suffering in time and the growing tragedy of uprootedness; earlier on, I had also done so in my Concurring Opinion (pars. 1-25) in this Court's Order of Provisional Measures of Protection (of 18.08.2000) in the case of the Haitians and Dominicans of Haitian Origin in the Dominican Republic, as well in my Separate Opinion (pars. 10-14) in the Bámaca Velásquez versus Guatemala case (Reparations, Judgment of 02.22.2002) ${ }^{21}$, and retook the point at issue the more recent Moiwana Community case ${ }^{22}$.

18 Ibid., pp. 21, 32, 181 and 197.

19 Ibid., pp. 212, 235, 266 and 278. On his concern with the need of preservation of memory, cf. also Elie Wiesel, L'oublié, Paris, Éd. Seuil, 1989, pp. 29, 63, 74-77, 109, 269, 278 and 336.

20 For the full text of my Separate Opinion in the case of the Moiwana Community versus Suriname, cf. A.A. Cançado Trindade, Derecho Internacional de los Derechos Humanos - Esencia y Trascendencia (Votos en la Corte Interamericana de Derechos Humanos, 1991-2006), Mexico, Edit. Porrúa/Universidad Iberoamericana, 2007, pp. 539-567.

21 For the full text of my aforementioned Concurring and Separate Opinions, cf. ibid., pp. 876-883 and 321 330 , respectively.

22 It is significant that, in its Judgment on the case of the Moiwana Community versus Suriname, the InterAmerican Court, on the basis of the American Convention and in the light of the principle jura novit curia, devoted a whole section of the present Judgment to forced displacement - a malaise of our times - and established a violation by the respondent State of Article 22 of the American Convention (on freedom of movement and residence) in combination with the general duty of Article 1(1) of the Convention (pars. 101-119). 
In fact, the projection of human suffering in time (its temporal dimension) has been properly acknowledged, e.g., in the final document of the U.N. World Conference against Racism, Racial Discrimination, Xenophobia and Related Intolerance (Dunbar, 2001), its adopted Declaration and Programme of Action. In this respect, it began by stating that:

We are conscious of the fact that the history of humanity is replete with major atrocities as a result of gross violations of human rights and believe that lessons can be learned through remembering history to avert future tragedies (par. 57).

It then stressed the "importance and necessity of teaching about the facts and truth of the history of humankind", with a view to "achieving a comprehensive and objective cognizance of the tragedies of the past" (par. 98). In this line of thinking, the Durban final document acknowledged and profounding regretted the "massive human suffering" and the "tragic plight" of millions of human beings caused by the atrocities of the past; it then called upon States concerned "to honour the memory of the victims of past tragedies", and affirmed that, wherever and whenever these occurred, "they must be condemned and their recurrence prevented" (par. 99).

The Durban Conference final document attributed particular importance to remembering the crimes and abuses of the past, in emphatic terms:

We emphasize that remembering the crimes or wrongs of the past, wherever and whenever they occurred, unequivocally condemning its racist tragedies and telling the truth about history, are essential elements for international reconciliation and the creation of societies based on justice, equality and solidarity (par. 106).

It at last recognized that "historical injustices" had undeniably contributed to the poverty, marginalization and social exclusion, instability and insecurity affecting so many people in distinct parts of the world (par. 158).

As well pointed out by Jaime Ruiz de Santiago, the drama of refugees and migrants, - of the uprooted in general, - can only be properly dealt with in a spirit of true human solidarity towards the victimized ${ }^{23}$. Definitively, only the firm determination of reconstruction of the international community ${ }^{24}$ on the basis of

23 Jaime Ruiz de Santiago, "Derechos Humanos, Migraciones y Refugiados: Desafios en los Inicios del Nuevo Milenio", in III Encuentro de Movilidad Humana: Migrante y Refugiado - Memoria (September 2000), San José of Costa Rica, UNHCR/IIHR, 2001, pp. 37-72; and cf. Jaime Ruiz de Santiago, Migraciones Forzadas Derecho Internacional y Doctrina Social de la Iglesia, Mexico, Instituto Mexicano de Doctrina Social Cristiana, 2004, pp. 9-82.

24 Cf., e.g., A.A. Cançado Trindade, "Human Development and Human Rights in the International Agenda of the XXIst Century", in Human Development and Human Rights Forum (August 2000), San José of Costa Rica, UNDP, 2001, pp. 23-38; cf. also, e.g., L. Lippolis, Dai Diritti dell'Uomo ai Diritti dell'Umanità, Milano, Giuffrè, 2002, pp. 21-23 and 154-155. 
human solidarity ${ }^{25}$ can lead to mitigating or alleviating some of the sufferings of the uprooted (whether refugees, internally displaced persons, or migrants).

\section{Basic Principles on Internal Displacement}

In the last three decades, the problem of internal displacement has challenged the very bases of the international norms of protection, demanding an aggiornamento of these latter and new responses to a situation not originally foreseen at the time of the drafting or elaboration of the relevant international instruments. These latter have revealed flagrant insufficiencies, such as, for example, the original lack of norms expressly directed to overcome the alleged non-applicability of the norms of protection no non-State actors, the nontipification of internal displacement under the original norms of protection, and the possibility of restrictions or derrogations undermining protection in critical moments. Such insufficiencies have generated initiatives of protection at both global (United Nations) and regional (Latin American) levels, - initiatives which have sought a conceptual framework which allows the development responses, at operative level, to the new needs of protection. It is quite proper to move on to a brief review of those initiatives.

\section{Global (United Nations) Level}

At global (U.N.) level, one decade ago, in the first trimester of 1998, the former U.N. Commission on Human Rights, bearing in mind the reports by the U.N. Secretary-General's Representative on Internally Displaced Persons (F.M. Deng) ${ }^{26}$, at last adopted the so-called Guiding Principles on Internal Displacement ${ }^{27}$, despite the persistence of the problem of internal displacement along mainly the last two decades. The basic purpose of the Guiding Principles is that of reinforcing and strengthening the already existing means of protection; to this effect, the proposed new principles apply both to governments and insurgent groups, at all stages of the displacement. The basic principle of non-discrimination occupies a central position in the aforementioned document of $1998^{28}$, which cares to list the same rights, of internally displaced persons, which other persons in their country enjoy ${ }^{29}$.

25 On the meaning of this latter, cf., in general, L. de Sebastián, La Solidaridad, Barcelona, Ed. Ariel, 1996, pp. 12-196; J. de Lucas, El Concepto de Solidaridad, 2nd. ed., Mexico, Fontamara, 1998, pp. 13-109; among others.

26 Those reports stressed the importance of prevention (e.g., reinforcing the protection of the rights to life and personal integrity, as well as the rights to property of lands and goods); cf. F.M. Deng, Internally Displaced Persons (Interim Report), N.Y., RPG/DHA, 1994, p. 21; and cf. U.N., doc. E/CN.4/1995/50/Add.1, of 03.10.1994, p. 34.

27 For comments, cf. W. Kälin, Guiding Principles on Internal Displacement - Annotations, Washington D.C., ASIL/Brookings Institution, 2000, pp. 1-276.

28 Principles 1(1), 4(1), 22, 24(1).

29 It affirms, moreover, the prohibition of the "arbitrary displacement" (Principle 6). 
The aforementioned 1998 Guiding Principles determine that the displacement cannot take place in a way that violates the rights to life, to dignity, to freedom and security of the affected persons ${ }^{30}$; they also assert other rights, such as the right to respect for family life, the right to an adequate standard of living, the right to equality before the law, the right to education ${ }^{31}$. The basic idea underlying the whole document ${ }^{32}$ is in the sense that the internally displaced persons do not lose their inherent rights, as a result of displacement, and can invoke the pertinent international norms of protection (of both International Human Rights Law and International Humanitarian Law) to safeguard their rights.

In a significant resolution adopted in 1994, the then U.N. Commission on Human Rights, bearing in mind in particular the problem of internally displaced persons, recalled the relevant norms of, altogether, International Human Rights Law and International Humanitarian Law, as well as International Refugee Law, of pertinence to the problem at issue ${ }^{33}$. Resolution 1994/68, adopted by the Commission on 03.09.1994, further recalled the 1993 Vienna Declaration and Programme of Action (adopted by the II World Conference on Human Rights), which called for "a comprehensive approach by the international community with regard to refugees and displaced persons" 34 .

It stressed the "humanitarian dimension" of "the problem of internally displaced persons and the responsibilities this poses for States and the international community" 35 . It further drew attention to "the need to address the root causes of internal displacement" 36 , as well as "to continue raising the level of consciousness about the plight of the internally displaced" 37 . More than a decade later, its considerations are likewise valid, nowadays, to migrants (cf. infra), who add an even greater dimension to the sufferings of the uprooted in our so-called and improperly called "globalized" world.

\section{Regional Level}

In the American continent, the 1984 Declarations of Cartagena on Refugees, the 1994 San José Declaration on Refugees and Displaced Persons, and the 2004 Mexico Declaration and Plan of Action to Strengthen the International

30 Principles 8 and following.

31 Principles 17, 18, 20 and 23, respectively.

32 On a "comprehensive approach" to displacement so as to address as well the problem of forced migration as a whole, bearing in mind the U.N. Guiding Principles on Internal Displacement, cf. C. Phuong, The International Protection of Internally Displaced Persons, Cambridge, University Press, 2004, pp. 54-55 and 237.

33 2nd. preambular paragraph.

347 th preambular paragraph.

35 th. preambular paragraph.

36 12th. preambular paragraph.

37 Paragraph 3 (emphasis added). 
Protection of Refugees in Latin America, are, each of them, product of a given historical moment. The first one, the Declaration of Cartagena, was motivated by urgent needs generated by a concrete crisis of great proportions; to the extent that this crisis was being overcome, due in part to that Declaration, its legacy began to project itself to other regions and subregions of the American continent.

The second Declaration was adopted amidst a distinct crisis, a more diffuse one, marked by the deterioration of the socio-economic conditions of wide segments of the population in distinct regions. In sum, Cartagena and San José were product of their time. The aggiornamento of the Colloquy of San José gave likewise a special emphasis on the identification of the needs of protection of the human being in any circumstances ${ }^{38}$. There remained no place for the vacatio legis $^{39}$. The 1994 Declaración of San José gave a special emphasis not only on the whole problem of internal displacement, but also, more widely, on the challenges presented by the new situations of human uprootedness in Latin America and the Caribbean, including the forced migratory movements originated by causes differents from those foreseen in the Declaration of Cartagena.

The 1994 Declaration recognized that the violation of human rights is one of the causes of forced displacements and that therefore the protection of those rights and the strengthening of the democratic system constitute the best measure for the search of durable solutions, as well as for the prevention of conflicts, the exoduses of refugees and the grave humanitarian crises ${ }^{40}$. Recently, at the end of consultations, with a wide public participation, undertaken at the initiative of the UNHCR, the 2004 Mexico Declaration and Plan of Action to Strengthen the International Protection of Refugees in Latin America was adopted ${ }^{41}$, on the occasion of the twentieth anniversary of the Cartagena Declaration (supra). For the first time in the present process, a document of the kind was accompanied by a Plan of Action. This can be explained by the aggravation of the humanitarian crisis in the region, particularly in the Andean subregion.

As the rapporteur of the Committee of Legal Experts of the UNHCR observed in his presentation of the final report to the Mexico Colloquy, at its first plenary session, on 15 November 2004, although the moments of the 1984 Cartagena Declaration and the 1994 San José Declaration are distinct, their achievements "cumulate, and constitute today a juridical patrimony" of all the peoples of the region, disclosing the new trends of the development of the

38 Instead of subjective categorizations of persons (in accordance with the reasons which led them to abandon their homes), proper of the past, nowadays the objective criterion of the needs of protection came to be adopted, encompassing thereby a considerably greater number of persons (including the internally displaced persons) so vulnerable as the refugees, or even more than these latter.

39 Ibid., pp. 14-15.

40 Ibid., pp. 431-432.

41 Cf. text reproduced in: UNHCR, Memoria del Vigésimo Aniversario de la Declaración de Cartagena sobre los Refugiados (1984-2004), Mexico City/San José of Costa Rica, UNHCR, 2005, pp. 385-398. 
international safeguard of the rights of the human person in the light of the needs of protection, and projecting themselves into the future ${ }^{42}$. Thus,

"the Declaration of Cartagena faced the great human drama of the armed conflicts in Central America, but furthermore foresaw the aggravation of the problem of internally displaced persons. The Declaration of San José, in turn, dwelt deeper upon the issue of protection of, besides refugees, also of internally displaced persons, but moreover foresaw the aggravation of the problem of forced migratory fluxes. Ever since anachronical compartmentalizations were overcome, proper of a way of thinking of a past which no longer exists, and one came to recognize the convergences between the three regimes of protection of the rights of the human person, namely, the International Law of Refugees, International Humanitarian Law and the International Law of Human Rights. Such convergences - at normative, hermeneutic and operative levels - were reaffirmed in all preparatory meetings of the present Commemorative Colloquy of Mexico City, and have repercussions nowadays in other parts of the world, conforming the most [more] lucid international legal doctrine on the matter" ${ }^{43}$.

Those convergences ${ }^{44}$ were, not surprisingly, further reflected in the 2004 Mexico Declaration and Plan of Action to Strengthen the International Protection of Refugees in Latin America itself. Thus, as the rapporteur of the Committee of Legal Experts of the UNHCR at last warned at the Mexico Colloquy of November 2004,

"there is no place for the vacatio legis, there is no legal vacuum, and all (...) persons are under the protection of the Law, in all and any circumstances (also in face of security measures)" 45 .

These developments are significant for addressing the issue of forced internal displacement, and the guarantee of voluntary and safe return. Yet, the problem of forced migrations has a wider dimension, and presents a considerable challenge nowadays to the international community as a whole. Only along the nineties the larger problem of the fluxes of forced migrations was identified and began to be dealt with as such, in a systematized way.

42 Cf. "Presentación por el Dr. A.A. Cançado Trindade del Comité de Consultores Jurídicos del ACNUR" (Mexico City, 15.11.2004), in UNHCR, Memoria del Vigésimo Aniversario de la Declaración de Cartagena..., op. cit. supra n. (41), pp. 368-369.

43 Ibid., p. 369.

44 Cf. A.A. Cançado Trindade, "Derecho Internacional de los Derechos Humanos, Derecho Internacional de los Refugiados y Derecho Internacional Humanitario: Aproximaciones y Convergencias", in 10 Años de la Declaración de Cartagena sobre Refugiados - Memoria del Coloquio Internacional (San José of Costa Rica, Dec. 1994), San José of Costa Rica, IIDH/UNHCR, 1995, pp. 77-168; A.A. Cançado Trindade, "Aproximaciones y Convergencias Revisitadas: Diez Años de Interacción entre el Derecho Internacional de los Derechos Humanos, el Derecho Internacional de los Refugiados, y el Derecho Internacional Humanitario (De Cartagena/1984 a San José/1994 y México/2004)", in Memoria del Vigésimo Aniversario de la Declaración de Cartagena sobre Refugiados (1984-2004), San José of Costa Rica, UNHCR, 2005, pp. 139-191.

45 Ibid., p. 369. 


\section{Basic Principles on Migrations}

By then, while the refugee population surpassed 18 million persons, and the displaced population surpassed that total in seven more million people (totalling 25 million persons $)^{46}$, the migrants in search of better living and working conditions, in turn, totalled 80 million human beings by the end of the XXth. century $^{47}$, and - according to IOM recent data - reach nowadays roughly 100 to 120 million migrants all over the world ${ }^{48}$.Yet, the suffering of migrants has been known for many years ${ }^{49}$.

The causes of forced migrations are not fundamentally distinct from those of populational forced displacement: natural disasters, chronic poverty, armed conflicts, generalized violence, systematic violations of human rights ${ }^{50}$. In the former U.N. Commission on Human Rights, it was pointed out that, in the midnineties, the challenge presented by this new phenomenon should be examined in the context of the reality of the post-cold war world, as a result of the multiple internal conflicts, of ethnic and religious character, repressed in the past but irrupted in recent years precisely with the end of the cold war ${ }^{51}$.

To these latter is added the growth of chronic poverty ${ }^{52}$. To face this new phenomenon of forced migrations, the U.N. General Assembly approved, on 12.18.1990, the International Convention on the Protection of the Rights of All Migrant Workers and Members of their Families. Such important Convention, which at last entered into force on 07. 01.2003, has, however, received very few ratifications, -36 so far (beginning of April 2007), - and has not yet been sufficiently dwelt upon by contemporary doctrine, despite its considerable significance. The 1990 Convention established the Committee on the Protection of the Rights of All Migrant Workers and Members of Their Families as its supervisory organ

46 F.M. Deng, Protecting the Dispossessed..., op. cit. supra n. (10), pp. 1 and 133.

47 A.A. Cançado Trindade, "Preface" to: V.O. Batista, Uniāo Européia: Livre Circulação de Pessoas e Direito de Asilo, Belo Horizonte/Brazil, Edit. Del Rey, 1998, p. 9.

48 Jaime Ruiz de Santiago, El Problema de las Migraciones Forzosas en Nuestro Tiempo, Mexico, IMDSC, 2003, p. 10; and cf. projections in: S. Hune and J. Niessen, "Ratifying the U.N. Migrant Workers Convention: Current Difficulties and Prospects", 12 Netherlands Quarterly of Human Rights (1994) p. 393.

49 On the adversities suffered by (foreign) migrant workers (e.g., discrimination on the basis of race, nationality, among others), cf., inter alia, S. Castles and G. Kosack, Los Trabajadores Inmigrantes y la Estructura de Clases en Europa Occidental, Mexico, FCE, 1984, pp. 11-565.

50 Cit. in F.M. Deng, Protecting the Dispossessed..., op. cit. supra n. (10), p. 3.

$51 \mathrm{Ibid}$., p. 4. - It has been warned that, in relation to migrants, the receiving State is always keen to display its power, and the distinct attitudes of Western European countries, of assimilation or else segregation of migrants, have had conflictive implications; E. Todd, El Destino de los Inmigrantes - Asimilación y Segregación en las Democracias Occidentales (transl. of Le destin des immigrés - Assimilation et ségrégation dans les démocraties occidentales), Barcelona, Tusquet Edit., 1996, pp. 147, 347, 351 and 353. The drama of migrants - their longing for roots and their own cultural identity - has thus persisted.

52 Which, in accordance with figures of the U.N. Development Programme (UNDP), only in Latin America victimizes today more than 270 million persons (compared to the 250 million of the eighties), who could soon get close to some 300 million people. 
(Article 72), entrusted with the examination of State reports (Articles 73-74) as well as inter-State and individual communications or complaints (Articles 76-77).

In the mid-nineties, the then U.N. Centre for Human Rights identified the caused of contemporary fluxes of migrant workers in extreme poverty (below subsistence level), search for work, armed conflicts, personal insecurity or persecution derived from discrimination (on the ground of race, ethnic origin, colour, religion, language or political opinions) ${ }^{53}$. The basic idea underlying the International Convention on the Protection of the Rights of All Migrant Workers and Members of their Families is that all migrant workers - thus qualified thereunder - ought to enjoy their human rights irrespective of their legal situation ${ }^{54}$.

Hence the central position occupied, also in this context, by the principle of non-discrimination (as set forth in its Article 7). Not surprisingly, the list of protected rights follows a necessarily holistic or integral vision of human rights (comprising civil, political, economic, social and cultural rights). The Convention took into account both the international labour standards (derived from the experience of the ILO - cf. infra), as well as those of the U.N. Conventions against discrimination ${ }^{55}$.

The protected rights are enunciated in three of the nine parts which conform the Convention: Part III (Articles 8-35) lists the human rights of all migrant workers and the members of their families (including the undocumented ones); Part IV (Articles 36-56) covers other rights of migrant workers and members of their families "who are documented or in a regular situation"; and Part V (Articles 57-63) contains provisions applicable to "particular categories" of migrant workers and members of their families ${ }^{56}$.

The basic principle of non-discrimination, which has a rather long history and to which so much importance was ascribed in the drafing process of the 1948 Universal Declaration of Human Rights ${ }^{57}$, and which subsequently became the main object of two important Conventions of the United Nations (CERD, 1966, and CEDAW, 1979), - which cover only some of its aspects, - has, only in recent years, been dwelt upon to a greater depth in its wide potential of application, as in the Advisory Opinions ns. 16 and 18 of the Inter-American Court of Human Rights, on The Right to Information on Consular Assistance in the Framework of the

53 U.N./Centre for Human Rights, Los Derechos de los Trabajadores Migratorios (Foll. Inf. n. 24), Geneva, U.N., 1996, p. 4.

54 Ibid., pp. 15-16.

55 Cf. ibid., p. 16.

56 That is, frontier workers, seasonal workers, itinerant workers, project-tied workers, with concrete employment, on their own, - in the terms of the definitions of Article 2(2) of the 1990 Convention. Article 2(1) defines "migrant worker" as "a person who is to be engaged, is engaged or has been engaged in a remunerated activity in a State of which he or she is not a national".

57 Cf. A. Eide et alii, The Universal Declaration of Human Rights - A Commentary, Oslo, Scandinavian University Press, 1992, p. 6. 
Guarantees of the Due Process of Law (1999), and on The Juridical Condition and Rights of the Undocumented Migrants (2003), respectively.

As, in the view of States, there is no human right to immigrate, the control of migratory entries is made subject to their own "sovereign" criteria, also to "protect" their internal markets ${ }^{58}$. Furthermore, instead of devising and applying true population policies bearing in mind human rights, most States have been exerting the strictly police function of "protecting" their own frontiers and controlling migratory fluxes, and sanctioning the so-called "illegal" migrants. The whole issue has been unduly and unnecessarily "criminalized".

It is thus not surprising that inconsistencies and arbitrarinesses ensue therefrom. These latter are manifested in "democratic regimes", the administration de justice of which, nevertheless, does not achieve to free itself from old prejudices against immigrants, even more so when they are undocumented and poor. The programs of "modernization" of justice, with international financing, do not dwell upon this aspect, as their main motivation is to ensure the security of investments (capitals and goods).

This provides a revealing picture of the (reduced) dimension which public authorities have conferred upon human beings at this beginning of the XXIst century, placed in a scale of priority inferior to that attributed to capitals and goods, - in spite of all the struggles of the past, and all the sufferings of previous generations. The area in which most incongruencies appear manifest nowadays is in effect the one pertaining to the guarantees of the due process of law.

Yet, the reaction of Law has become prompt and manifest in our days, as demonstrated, for example, by the pioneering Advisory Opinions ns. 16 and 18 of the Inter-American Court of Human Rights, on The Right to Information on Consular Assistance in the Framework of the Guarantees of the Due Process of Law (1999), and on The Juridical Condition and Rights of the Undocumented Migrants (2003), respectively. The Advisory Opinion n. 16 has placed the right to consular notification, set forth in Article 36(1) (b) of the 1963 Vienna Convention on Consular Relations in the conceptual universal of International Human Rights Law. It has indeed conferred a human rights dimension to some postulates of classic consular law, as I pointed out in my Concurring Opinion (pars. 1-35) ${ }^{59}$ in the Court's aforementioned 16th. Advisory Opinion.

Since it was issued by the Court, the 16th. Advisory Opinion, besides inspiring the international case-law in statu nascendi, has had a considerable impact on international practice in the American continent (more particularly,

58 M. Weiner, "Ethics, National Sovereignty and the Control of Immigration", 30 International Migration Review (1996) pp. 171-195.

59 Cf. text in: A.A. Cançado Trindade, Derecho Internacional de los Derechos Humanos - Esencia y Trascendencia (Votos en la Corte Interamericana de Derechos Humanos, 1991-2006), Mexico, Edit. Porrúa/Universidad Iberoamericana, 2007, pp. 15-27. 
in Latin America ${ }^{60}$. Yet, there is much need of greater and genuine international cooperation to secure assistance to, and protection of, all migrants and members of their families. Legal norms can hardly be effective without the corresponding and underlying values, and, in the present domain, the application of the relevant norms of protection does require a fundamental change of mentality.

In relation to the subject at issue, the norms already exist, but the proper acknowledgment of values seem to be still lacking, as well as a new mentality. It is not mere casuality that the International Convention on the Protection of the Rights of All Migrant Workers and Members of their Families, despite having entered into force on 07.01.2003, as already pointed out, has not many ratifying States so far ${ }^{61}$ (cf. supra). Despite the identity of the basic principles and of the applicable law in distinct situations, the protection of migrants requires, nevertheless, a special emphasis on one and the other aspect in particular. The starting-point seems to lie on the recognition that every migrant has the right to enjoy all the fundamental human rights, as well as the rights derived from the employments occupied in the past, irrespective of his juridical situation (whether irregular or not).

Here, once again, a necessarily holistic or integral vision of all human rights (civil, political, economic, social and cultural) applies. Just as the principle of nonrefoulement constitutes the cornerstone of the protection of refugees (as a principle of customary law and, furthermore, of jus cogens), applicable in other situations as well, in the matter of migrants (mainly the undocumented ones) it assumes special importance, beside the due process of law (supra); thus, the fundamental human rights and the dignity of irregular or undocumented migrants ought to be preserved also in face of threats of deportation and/or expulsion ${ }^{62}$. Every person

60 Cf. A.A. Cançado Trindade, "The Humanization of Consular Law: The Impact of Advisory Opinion n. 16 (1999) of the Inter-American of Human Rights on International Case-Law and Practice", 4 Chinese Journal of International Law (2007) pp. 1-16.

61 In some cases, the insufficiencies of the instruments of protection result from the very formulation of some of their norms. For example, in so far as the protection of statesless persons is concerned, the 1954 Convention Relating to the Status of Stateless Persons (and, implicitly, also the 1961 Convention of the Reduction of Statelessness) only refers to stateless persons de jure, so as to avoid statelessness as of birth, but failing to prohibit - what would perhaps be more relevant - the revocation or loss of nationality in given circumstances; C.A. Batchelor, "Stateless Persons: Some Gaps in International Protection", 7 International Journal of Refugee Law (1995) pp. 232-255.

62 For a compelling argument against arbitrariness in the deportation of migrants, and in support of treating all migrants (including the undocumented ones) with fairness, and a sense of worth and humanity, cf. B.O. Hing, Deporting Our Souls - Values, Morality and Immigrantion Policy, Cambridge, University Press, 2006, pp. 1-215. On the provisions of the International Convention on the Protection of the Rights of All Migrant Workers and Members of their Families against unfair and arbitrary expulsion of migrants, pursuant to humanitarian considerations, cf. R. Cholewinski, Migrant Workers in International Human Rights Law - Their Protection in Countries of Employment, Oxford, Clarendon Press, 1997, pp. 182-184. And, on the prohibition of massive expulsion of foreigners, cf. A.A. Cançado Trindade, "El Desarraigo como Problema de Derechos Humanos frente a la Conciencia Jurídica Universal", in Movimientos de Personas e Ideas y Multiculturalidad (Forum Deusto), vol. I, Bilbao, University of Deusto, 2003, pp. 82-84; H.G. Schermers, "The Bond between Man and State", Recht zwischen Umbruch und Bewahrung - Festschrift für R. Bernhardt (eds. U. Beyerlin et alii), Berlin, Springer-Verlag, 1995, pp. 192-194; H. Lambert, "Protection against Refoulement from Europe: Human Rights Law Comes to the Rescue", 48 International and Comparative Law Quarterly (1999) pp. 515-518. 
in such a situation has the right to be heard by a judge and not to be detained ilegally or arbitrarily ${ }^{63}$.

The International Convention on the Protection of the Rights of All Migrant Workers and Members of their Families prohibits measures of collective expulsion, and determines that each case of expulsion ought to be "examined and decided individually" (Article 22(1)), in accordance with the law. Given the great vulnerability which accompanies the migrants in situation of irregularity, the countries of both origin and admission should take positive measures to ensure that all migrations take place in a regular way ${ }^{64}$. This is a challenge to all countries, and even more forcefully to those which purport to be "democratic". Last but not least, the 1990 Convention ought to be properly appreciated in conjunction with the 1966 U.N. Covenant on Civil and Political Rights, as well the relevant I.L.O. Conventions on the matter ${ }^{65}$.

\section{The Protection of Migrants in International Case-Law}

\section{European Human Rights System}

The theme of aliens or migrants has marked its presence in the normative and operational levels of the European system of human rights protection. Thus, Protocol n. 4 (of 1963) to the European Convention on Human Rights effectively prohibits the collective expulsion of foreigners (Article 4). And even in individual cases, if the expulsion of a foreigner generates a separation of the members of the family unit, it brings about a violation of Article 8 of the European Convention of Human Rights; accordingly, the States Parties to this latter no longer have total discretionality to expell from their territory foreigners who already have established a "genuine link" with them ${ }^{66}$.

The limits of State discretionality as the treatment of any persons under the jurisdiction of the States Parties to human rights treaties were stressed, e.g., in the well-known early cases of the East African Asians. In those cases, the old European Commission of Human Rights concluded that 25 of the complainants (who had retained their status of British citizens after the independence of Kenya

63 Resettlement, within a reasonable time, in a third country, should also be considered; cf. "Los Derechos y las Obligaciones de los Migrantes Indocumentados en los Países de Acogida / Protección de los Derechos Fundamentales de los Migrantes Indocumentados", 21 International Migration / Migraciones Internacionales (1983) pp. 135-136.

64 Cf. ibid., p. 136.

65 Namely, the 1949 Migration (n. 97) for Employment Convention (Revised), and the 1975 Convention (n. 143) concerning Migrant Workers, as well as Recommendation n. 151 concerning Migrant Workers (of 1975). For a contextual discussion, cf., e.g., B. Boutros-Ghali, "The U.N. and the I.L.O.: Meeting the Challenge of Social Development", in Visions of the Future of Social Justice - Essays on the Occasion of the I.L.O.'s 75th Anniversary, Geneva, I.L.O., 1994, pp. 51-53.

66 H.G. Schermers, "The Bond between Man and State", Recht zwischen Umbruch und Bewahrung..., op. cit. supra n. (62), pp. 192-194. 
and Uganda to see themselves free from migratory controls) had been victimized by a new British law which put an end to the right of entry of British citizens who did not have ancestral links with the United Kingdom. In the understanding of the old European Commission (Report of 1973), this law constituted an act of racial discrimination which characterized a "degrading treatment" in the terms of Article 3 of the European Convention of Human Rights ${ }^{67}$.

Years later, the same European Commission confirmed its position on the matter, in the case Abdulaziz, Cabales and Balkandali versus United Kingdom (1983), wherein it warned the State discretionality in the matter if immigration has its limits, as a State cannot, e.g., implement policies based upon racial discrimination ${ }^{68}$. The case was referred to the European Court by the Commission, as the three applicants (Mrs. Abdulaziz, Mrs. Cabales and Mrs. Balkandali, lawfully and permanently settled in the United Kingdom, had been refused to join their husbands in that country). On its turn, the European Court, in its Judgment (1985) found a violation, not of Article 8 per se, but of Article 8 (respect for private and family life) together with Article 14 (prohibition of discrimination), by reason of discrimination on the ground of $\operatorname{sex}^{69}$.

In addition, in the case Abdulaziz, Cabales and Balkandali, the Court further established a violation of 13 of the Convention, for lack of access to justice; the Court pondered that

"the discrimination on the ground of sex of which Mrs. Abdulaziz, Mrs. Cabales and Mrs. Balkandali were victims was the result of norms that were in this respect incompatible with the Convention. In this regard, since the United Kingdom has not incorporated the Convention into its domestic law, there could be no "effective remedy" as required by Article 13 "'70.

In his Concurring Opinion in the Abdulaziz, Cabales and Balkandali case, Judge R. Bernhardt aptly argued that:

"Article 13 must, in my view, be given a meaning which is independent of the question whether any other provision of the Convention is in fact violated. Whenever a person complains that one of the provisions of the Convention itself or any similar

67 Despite the fact that the case was never lodged with the European Court of Human Rights, and that the Committee of Ministers did not pronounce on such violation of the European Convention, it awaited until all the complainants were admitted to the United Kingdom to conclude that if was no longer necessary to take any other measure. D.J. Harris, M. O'Boyle and C. Warbrick, Law of the European Convention on Human Rights, London, Butterworths, 1995, pp. 81-82 and 695.

68 Cit. in ibid., p. 82. - The old European Commission cared to characterize the "collective expulsion of foreigners", for the purpose of application of the prohibition contained in Article 4 of Protocol n. 4 to the European Convention, as illustrated, e.g., by its considerations in the case $A$. et alii versus The Netherlands (1988), interposed by 23 applicants of Surinamese nationality; cf. European Commission of Human Rights, application n. 14209/88 (decision of 16.12.1988), in Decisions and Reports, vol. 59, Strasbourg, C.E., 1989, pp. 274-280.

69 Paragraphs 83 and 86, and resolutory point n. 3 .

70 Paragraph 93, and resolutory point n. 6. 
guarantee or principle contained in the national legal system is violated by a national (administrative or executive) authority, Article 13 is in my view applicable and some remedy must be available" 71 .

In spite of the fact that the European Convention itself did not contemplate the right not to be expelled from on the States Parties, very soon in the operation of the European Convention it was accepted that there were limits to the faculty of the States Parties to control the entry and departure of foreigners, virtue of the obligations contracted under the Convention itself, as illustrated, e.g., by those pertaining to Article 8 (on the right to respect for private and family life). Thus, although there does not exist a general definition of "family life", very soon a protecting case-law was developed in this respect, in the light of the circumstances of each concrete case. Such case-law, bearing in mind, inter alia, the principle of proportionality, has stipulated restrictively the conditions of expulsion ${ }^{72}$.

A study of the protection of migrant workers in the International Law of Human Rights has recalled that, on several occasions, the European Court found "an infringement of the right to respect for family life in cases involving second-generation migrants, who had either been expelled, or were under threat of expulsion, because they had been convicted of criminal offences in their country of residence"73. Although in each case the expulsions, or threatened expulsions, aimed at preventing disorder or crime, they constituted - the study went on, recalling inter alia the Court's Judgments in the cases of Beldjoudi versus France (of 03.26.1992) and Moustaquim versus Belgium (of 02.18.1991), - "a disproportionate means of achieving this aim given that the affected individuals had spent most of their lives, together with their immediate families, in the countries concerned and had little or no ties with their country or origin" 74 .

The Beldjoudi and the Moustaquim cases, together with the Lamguindaz versus United Kingdom case (1992), are nowadays regarded as leading cases in this particular respect. As forcefully argued in another study on the matter, given the links (such as family and social ties, schooling, understanding of culture and language) between second-generation migrants and their (new) country of residence, they are de facto citizens, and their deportation or expulsion would amount to a violation of their right to private and family life (Article 8 of the

71 ECtHR, case of Abdulaziz, Cabales and Balkandali, Judgment (28.05.1985), Strasbourg, C.E., 1985, Concurring Opinion of Judge R. Bernhardt, p. 41.

72 Bearing in mind the provision of Article 8 of the European Convention; cf. M.E. Villiger, "Expulsion and the Right to Respect for Private and Family Life (Article 8 of the Convention) - An Introduction to the Commission's Case-Law", in Protecting Human Rights: The European Dimension - Studies in Honour of G.J. Wiarda / Protection des droits de l'homme: La dimension européenne - Mélanges en l'honneur de G.J. Wiarda (eds. F. Matscher and H. Petzold), Köln/Berlin, C. Heymanns Verlag, 1988, pp. 657-658 and 662.

73 R. Cholewinski, Migrant Workers in International Human Rights Law - Their Protection in Countries of Employment, Oxford, Clarendon Press, 1997, p. 341.

74 Ibid., pp. 341-342. 
European Convention) ${ }^{75}$. The protection of the human rights of migrants, under given circumstances, has thus found judicial recognition in the European human rights system. It has done so also in the inter-American human rights system, which has gone even further than the European one in this respect, as it will be indicated next.

\section{Inter-American Human Rights System}

The protection of or migrants has likewise marked its presence in the normative and operational levels of the Inter-American system of human rights protection. It has, in fact, been remarkably present in the case-law of the InterAmerican Court of Human Rights in recent years. I have already referred to the Court's Judgment (of 06.15.2005) on the case of the Moiwana Community versus Suriname, as well as the Court's Order of Provisional Measures of Protection (of 08.18.2000) in the case of the Haitians and Dominicans of Haitian Origin in the Dominican Republic. In this latter, in my Concurring Opinion, I saw it fit to warn as to the pressing need to face the contemporary tragedy of uprootedness, and I further argued that:

"the principle of non-refoulement, cornerstone of the protection of refugees (as a principle of customary law and also of jus cogens), can be invoked even in distinct contexts, such as that of the collective expulsion of (...) migrants or of other groups. Such principle has been set forth also in human rights treaties, as illustrated by Article 22(8) of the American Convention on Human Rights" ${ }^{276}$.

The relevance of this approach to the point at issue, in relation to the Court's Order of Provisional Measures of Protection in the aforementioned case of the Haitians and Dominicans of Haitian Origin in the Dominican Republic, has been promptly acknowledged in expert writing ${ }^{77}$.

As for the already mentioned Judgment of the Inter-American Court, of 06.15.2005, on the case of the Moiwana Community versus Suriname, it was followed by an Interpretation of Sentence (of 02.08.2006), to which I appended a Separate Opinion, wherein I dwelt upon the following points: a) the delimitation, demarcation and titling and return of land (to the surviving members of the

75 R. Cholewinski, “Strasbourg's 'Hidden Agenda'?: The Protection of Second-Generation Migrants from Expulsion under Article 8 of the European Convention of Human Rights", 12 Netherlands Quarterly of Human Rights (1994) pp. 287-306. - For the obiter dicta of the European Court of Human Rights on the question of "long-term immigrants", despite the fact that it found no violation of Article 8 of the European Convention in the cas d'espèce, cf. ECtHR, case of Uner versus Netherlands, Judgment of 18.10.2006, pars. 55-60.

76 Paragraph 7 n. 5 of my Concurring Opinion (my own translation), text in: A.A. Cançado Trindade, Derecho Internacional de los Derechos Humanos - Esencia y Trascendencia (Votos en la Corte Interamericana de Derechos Humanos, 1991-2006), Mexico, Edit. Porrúa/Universidad Iberoamericana, 2007, p. 878.

77 Cf. Jaime Ruiz de Santiago, El Problema de las Migraciones Forzosas en Nuestro Tiempo, Mexico, Instituto Mexicano de Doctrina Social Cristiana, 2003, pp. 27-30. 
Moiwana Community and their relatives) as a form of reparation); b) the State's duty of guarantee of voluntary and sustainable return; and c) the need of reconstruction and preservation of the cultural identity of the members of the Moiwana Community ${ }^{78}$.

Furthermore, the great adversity undergone by migrants was properly addressed, and duly emphasized, in the course of whole advisory proceedings before the Inter-American Court of Human Rights conducive to the adoption of its historical 16th. and 18th. Advisory Opinions, of 1999 and 2003, respectively. Both Opinions were pioneering in contemporary international case-law (infra), and represent the reaction of Law to situations of violations of human rights in large scale, of persons who at times find themselves in total defencelessness. It is thus proper to review, at this stage, the contribution of those two remarkable Advisory Opinions to the safeguard of the human rights of undocumented migrants.

a) The Advisory Opinion on the Right to Information on Consular Assistance in the Framework of the Due Process of Law (1999).

The Inter-American Court delivered, on 10.01.1999, the sixteenth Advisory Opinion of its history, on the Right to Information on Consular Assistance in the Framework of the Due Process of Law. In that sixteenth Advisory Opinion, of transcendental importance, the Court held that Article 36 of the 1963 Vienna Convention on Consular Relations recognizes to the foreigner under detention individual rights, - among which the right to information on consular assistance, - to which correspond duties incumbent upon the receiving State (irrespective of its federal or unitary structure) (pars. 84 and 140).

The Inter-American Court pointed out that the evolutive interpretation and application of the corpus juris of the International Law of Human Rights have had "a positive impact on International Law in affirming and developing the aptitude of this latter to regulate the relations between States and human beings under their respective jurisdictions". The Court thus adopted the "proper approach" in considering the matter submitted to it in the framework of "the evolution of the fundamental rights of the human person in contemporary International Law" (pars. 114-115). The Court stated that "human rights treaties are living instruments, whose interpretation ought to follow the evolution of times and the current conditions of life" (par. 114). The Court made it clear that, in its interpretation of the norms of the American Convention on Human Rights, it should aim at extending protection in new situations on the basis of preexisting rights.

The Court expressed the view that, for the due process of law to be preserved, "a defendant must be able to exercise his rights and defend his interests effectively

78 For the full text of my Separate Opinion in the case of the Moiwana Community versus Suriname (Interpretation of Sentence, of 08.02.2006), cf. A.A. Cançado Trindade, Derecho Internacional de los Derechos Humanos - Esencia y Trascendencia (Votos en la Corte Interamericana de Derechos Humanos, 1991-2006), Mexico, Edit. Porrúa/ Universidad Iberoamericana, 2007, pp. 683-693. 
and in full procedural equality with other defendants" (par. 117). In order to attain its objectives, "the judicial process ought to recognize and correct the factors of real unequality" of those taken to justice (par. 119); thus, the notification, to persons deprived of their liberty abroad, of their right to communicate with their consul, contributes to safeguard their defence and the respect for their procedural rights (pars. 121-122). The individual right to information under Article 36(1) (b) of the Vienna Convention on

Consular Relations thus renders effective the right to the due process of law (par. 124).

The non-observance or obstruction of the exercise of this right affects the judicial guarantees (par. 129). The Court in this way linked the right at issue to the evolving guarantees of due process of law, and added that its non-observance in cases of imposition and execution of death penalty amounts to an arbitrary deprivation of the right to life itself (in the terms of Article 4 of the American Convention on Human Rights and Article 6 of the International Covenant on Civil and Political Rights), with all the juridical consequences inherent to a violation of the kind, that is, those pertaining to the international responsibility of the State and to the duty of reparation (par. 137) ${ }^{79}$.

This 16th. Advisory Opinion of the Court, truly pioneering, has served as inspiration for the emerging international case-law, in statu nascendi, on the matter ${ }^{80}$, and is having a sensible impact on the practice of the States of the region on the issue ${ }^{81}$. Its advisory proceedings counted on a considerable mobilization (with 8 intervening States, besides several non-governmental organizations and individuals ${ }^{82}$. This historical Advisory Opinion n. 16, furthermore, reveals the impact of the International Law of Human Rights in the evolution of Public International Law itself, specifically for having the Inter-American Court been the first international tribunal to warn that, if non-compliance with Article 36(1) (b)

79 And cf. Concurring Opinions of Judges A.A. Cançado Trindade and S. García Ramírez, and Partially Dissenting Opinion of Judge O. Jackman.

80 As promptly acknowledged by expert writing; cf., e.g., G. Cohen-Jonathan, "Cour Européenne des Droits de l'Homme et droit international général (2000)”, 46 Annuaire français de Droit international (2000) p. 642; M. Mennecke, "Towards the Humanization of the Vienna Convention of Consular Rights - The LaGrand Case before the International Court of Justice", 44 German Yearbook of International Law/Jahrbuch für internationales Recht (2001) pp. 430-432, 453-455, 459-460 and 467-468; L. Ortiz Ahlf, De los Migrantes - Los Derechos Humanos de los Refugiados, Asilados, Desplazados e Inmigrantes Irregulares, Mexico, Ed. Porrúa/Univ. Iberoamericana, 2004, pp. 1-68; Ph. Weckel, M.S.E. Helali and M. Sastre, "Chronique de jurisprudence internationale", 104 Revue générale de Droit international public (2000) pp. 794 and 791; Ph. Weckel, "Chronique de jurisprudence internationale", 105 Revue générale de Droit international public (2001) pp. 764-765 and 770.

81 Cf. A.A. Cançado Trindade, "The Humanization of Consular Law: The Impact of Advisory Opinion n. 16 (1999) of the Inter-American of Human Rights on International Case-Law and Practice", 4 Chinese Journal of International Law (2007) pp. 1-16.

82 In the public hearings (on this 16th. Advisory Opinion) before the Court, apart from the 8 intervening States, several individuals took the floor, namely: 7 individuals representatives of 4 national and international nongovernmental organizations (active in the field of human rights), 2 individuals of a non-governmental organization working for the abolition of the death penalty, 2 representatives of a (national) entity of lawyers, 4 University Professors in their individual capacity, and 3 individuals in representation of a person condemned to death. 
of the Vienna Convention on Consular Relations of 1963 takes place, it occurs to the detriment not only of a State Party but also of the human beings at issue ${ }^{83}$.

In the same line of thinking, Advisory Opinion n. 18 opens new ground for the protection of migrants, in acknowledging the character of jus cogens of the basic principle of equality and non-discrimination, and the prevalence of the rights inherent to human beings, irrespective of their migratory States. Its advisory proceedings counted on an even greater mobilization (with 12 accredited States, in addition to the UNHCR, several non-governmental organizations, academic institutions and individuals), the greatest in the whole history of the Court to date. This more recent Opinion n. 18 is likewise having an impact on the theory and practice of International Law in the present domain of protection of the human rights of migrants ${ }^{84}$.

b) The Advisory Opinion on the Juridical Condition and Rights of Undocumented Migrants (2003).

On 10 May 2002 Mexico requested the Inter-American Court of Human Rights its 18th Advisory Opinion, on the juridical condition and rights of undocumented migrants. In the course of the corresponding advisory proceedings, which counted on the greatest public participation in the whole history of the Court, the Court celebrated two public hearings, the first in its headquarters in San José of Costa Rica, in February 2003, and the second outside its headquarters (for the first time in its history), in Santiago of Chile, in June 2003. The advisory procedure counted with the participation of twelve accredited States (among which five States intervening in the hearings), the Inter-American Commission on Human Righs, one agency of the United Nations (the U.N. High Commission for Refugees - UNHCR), and nine entities of the civil society and academic circles of several countries of the region, besides the Central American Council of Human Rights Ombudsmen [Attorneys-General].

On 17 September 2003 the Inter-American Court of Human Rights delivered its 18th Advisory Opinion (requested by Mexico), on the Juridical Condition and Rights of Undocumented Migrants, wherein it held that States ought to respect

83 As the ICJ has subsequently also admitted, in the LaGrand case.

84 As also promptly acknowledged by expert writing; cf., e.g., L. Hennebel, "L'humanisation' du Droit international des droits de l'homme - Commentaire sur l'Avis Consultatif n. 18 de la Cour Interaméricaine relatif aux droits des travailleurs migrants", 15 Revue trimestrielle des droits de l'homme (2004) n. 59, pp. 747-756; S.H. Cleveland, "Legal Status and Rights of Undocumented Migrants - Advisory Opinion OC-18/03 [of the] Inter-American Court of Human Rights", 99 American Journal of International Law (2005) pp. 460-465; C. Laly-Chevalier, F. da Poïan and H. Tigroudja, "Chronique de la jurisprudence de la Cour Interaméricaine des Droits de l'Homme (2002-2004)", 16 Revue trimestrielle des droits de l'homme (2005) n. 62, pp. 459-498. And cf. also, on the impact of the Advisory Opinion n. 18 of the IACtHR in the United States, R. Smith, "Derechos Laborales y Derechos Humanos de los Migrantes en Estatus Irregular en Estados Unidos", in Memorias del Seminario Internacional 'Los Derechos Humanos de los Migrantes' (Mexico, June 2005), Mexico, Secretaría de Relaciones Exteriores, 2005, pp. 299-301. 
and ensure respect of human rights in the light of the general and basic principle of equality and non-discrimination, and that any discriminatory treatment with regard to the protection and exercise of human rights generates the international responsibility of the States. In the view of the Court, the fundamental principle of equality and non-discrimination has entered into the domain of jus cogens.

The Court added that States cannot discriminate or tolerate discriminatory situations to the detriment of migrants, and ought to guaranteee the due process of law to any person, irrespective of her migratory status. This latter cannot be a justification for depriving a person of the enjoyment and exercise of her human rights, including labour rights. Undocumented migrant workers have the same labour rights as the other workers of the State of employment, and this latter ought to ensure respect for those rights in practice. States cannot subordinate or condition the observance of the principle of equality before the law and nondiscrimination to the aims of their migratory or other policies.

In addition, Individual Opinions were presented by four Judges, all of them being, significantly, Concurring Opinions. In his extensive Concurring Opinion, the President of the Court, Judge A.A. Cançado Trindade, dwelt upon nine points, namely: a) the civitas maxima gentium and the universality of the human kind; b) the disparities of the contemporary world and the vulnerability of the migrants; c) the reaction of the universal juridical conscience; d) the construction of the individual subjective right of asylum; e) the position and the role of the general principles of Law; f) the fundamental principles as substratum of the legal order itself; g) the principle of equality and non-discrimination in the International Law of Human Rights; h) the emergence, the content and the scope of the jus cogens; and i) the emergence and the scope of the obligations erga omnes of protection (their horizontal and vertical dimensions).

The 18th Advisory Opinion of the Inter-American Court, on the Juridical Condition and Rights of Undocumented Migrants, has already had, for all its implications, a considerable impact in the American continent, and its influence is bound to irradiate elsewhere as well, given the importance of the matter. It propounds the same the dynamic or evolutive interpretation of International Human Rights Law heralded by the Inter-American Court, four years ago, in its pioneering 16th Advisory Opinion, on The Right to Information on Consular Assistance in the Framework of the Guarantees of the Due Process of Law (1999) ${ }^{85}$, which has ever since been a source of inspiration for the international case-law in statu nascendi on the matter. In 2003, the Inter-American Court has reiterated and expanded on in its forward-looking outlook, in its 18th Advisory Opinion, on the Juridical Condition and Rights of Undocumented Migrants, constructed upon the evolving concepts of jus cogens and of obligations erga omnes of protection.

85 In that 16th and pioneering Advisory Opinion, of major importance, the Inter-American Court clarified that, in its interpretation of the norms of the American Convention, it should extend protection in new situations (such as that concerning the observance of the right to information on consular assistance) on the basis of preexisting rights (supra). 


\section{The Protection of Migrants in Rapporteur Systems}

The protection of the human rights of migrants has indeed become a key issue in the international human rights agenda of this first decade of the XXIst. century. This is hardly surprising, given the growing awareness of the relationships between the intensification of migratory fluxes (from the late eighties onwards), the speedy internationalization of capitalism, and the growing labour exploitation (generated by the "requirements of capital", and with the high human costs of unemployment and underemployment, "informality" in labour relations, search for cheap manpower, impoverishment of livig conditions of large segments of the population, and concentration of wealth and income in world scale) ${ }^{86}$.

It was all too expected that, in the nineties, the theme was to become object of increased attention on the part of international organizations at both universal (United Nations) and regional (Organization of American States) levels. At global level, lucid voices from within the Office of the U.N. High Commissioner for Refugees (UNHCR) warned that the UNHCR could no longer work for the protection only of refugees, but should also take into account the denial of human rights of internally displaced persons as well as migrants, and work for their protection, together with that of refugees ${ }^{87}$. In this connecion, it should not pass unnoticed that the UNHCR actually intervened in the oral hearings before the Inter-American Court of Human Rights, in the advisory proceedings that led to the adoption by the Inter-American Court of its Advisory Opinion n. 18 on The Juridical Condition and Rights of the Undocumented Migrants (of.09.172003) ${ }^{88}$.

Moreover, international organizations, prompted by the new phenomenon of the intensification of fluxes of forced migrations, have decided - both the United Nations and the Organization of American States - to insert it into the scheme of work of their respective rapporteur systems. The mandate of the U.N. Special Rapporteur on the Human Rights of Migrants was created in 1999, by resolution 1999/44 of the former U.N. Commission on Human Rights (par. 3). The resolution entrusted the Special Rapporteur with the tasks of elaboration of reports and undertaking of country visits, and further requested the Special Rapporteur to examine "ways and means to overcome the obstacles existing to the full and effective protection of the human rights of migrants" ${ }^{\prime 9}$.

86 Cf., e.g., A.M. Aragonés Castañer, Migración Internacional de Trabajadores - Una Perspectiva Histórica, Mexico, Edit. Plaza y Valdés, 2004 [reimpr.], pp. 21, 23, 54, 62, 71-73, 115-120, 125-126, 148 and 154-157.

87 Jaime Ruiz de Santiago, "El Impacto en el Refugio de la Nueva Dinámica Migratoria en la Región - Retos para Asegurar la Protección de Refugiados", in IIHR, Primer Curso de Capacitación para Organizaciones de la Sociedad Civil sobre Protección de Poblaciones Migrantes (June 1999), Mexico/San José of Costa Rica, UNHCR/ Universidad Iberoamericana/IIHR, 2002, p. 43; Juan Carlos Murillo, "La Declaración de Cartagena, el Alto Comisionado de Naciones Unidas para los Refugiados y las Migraciones Mixtas", in Migraciones y Derechos Humanos (August 2004), San José of Costa Rica, IIHR/PRODECA, 2004, pp. 174-176.

88 For the pleadings of the UNHCR before the Inter-American Court, cf. IACtHR, Series B (Pleadings, Oral Arguments and Documents), n. 18 (2003), pp. 211-223 (oral argument of 04.06.2003).

89 U.N., Special Rapporteur of the [U.N.] Commission on Human Rights on the Human Rights of Migrants, doc. www.ohchr.org, 2nd. paragraph. 
Resolution 1999/44 drew attention to the "large and increasing number of migrants in the world" in a "situation of vulnerability", and stressed "the need for a focused and consistent approach towards migrants as a specific vulnerable group" 90 . In pursuance of that mandate, a series of reports have been prepared and presented by the Special Rapporteur, who, in the period 2000-2005, has also undertaken country visits to Canada, Ecuador, Philippines, border Mexico/ United States, Mexico, Spain, Morocco, Iran, Italy, Peru and Burkina Faso.

In 2005, the then U.N. Commission on Human Rights enlarged the mandate of the Special Rapporteur, foreseeing the adoption of appropriate policies on migrants, - having as a priority the protection of the human rights of migrants, - stressing the duty of States to prevent and sanction acts of private individuals attempting against the life and personal integrity of migrants, and securing the recognition by the international community of the situation of vulnerability faced by migrants ${ }^{91}$. This is an important aspect of the matter at issue; in fact, recent and substantial studies on migrations have focused on the framework of legislative initiatives on a comparative law basis ${ }^{92}$, or in a regional ambit (e.g., that the European Union) $)^{93}$, - focusing on the regulatory or normative structure, but without portraying sufficiently the dramatic situation of vulnerability of migrants (whether documented or undocumented), all in pressing need of protection.

In fact, still at global (U.N.) level, resolution 2005/47 of the former U.N. Commission on Human Rights, adopted on 04.19.2005, expressed concern, in its preamble, at "the increasing number of migrants worldwide", a worrisome phenomenon with a "global character" (par. 6), and called upon States to revise their immigration policies with a view to eliminate all discriminatory practices against migrants and their families (par. 4). It urged States to put an end to arbitrary arrests and deprivation of liberty of migrants (par. 15), to prevent the violation of the human rights of migrants while in transit (par. 18), and to combat and prosecute international trafficking and smuggling of migrants (endangering their lives and entailing "different forms of servitude or exploitation" - par. 19) ${ }^{94}$. Resolution 2005/47, recalled, in its preamble, the contributions of the pioneering Advisory Opinions ns. 16 and 18 of the Inter-American Court of Human

90 4th., 6th. and 7th. preambular paragraphs.

91 Cf. comments in: E.D. Estrada Tanck, "Legislación y Políticas Públicas Mexicanas: Armonización con el Régimen Jurídico Internacional sobre Derechos Humanos de los Migrantes”, in Memorias del Seminario Internacional 'Los Derechos Humanos de los Migrantes', (Mexico, June 2005), Mexico, Secretaría de Relaciones Exteriores, 2005, pp. 330-331; C. Villán Durán, "Los Derechos Humanos y la Inmigración en el Marco de las Naciones Unidas", in ibid., pp. 95-98.

92 Cf., inter alia, Federación Iberoamericana de Ombudsman, I Informe sobre Derechos Humanos - Migraciones (coord. G. Escobar), Madrid, Ed. Dykinson/Depalma, 2003, pp. 47-420.

93 Cf., e.g., P.A. Fernández Sánchez, Derecho Comunitario de la Inmigración, Barcelona, Atelier, 2006, pp. 15-325.

94 The resolution further encouraged States Parties to implement fully the U.N. Convention against Transnational Organized Crime and the two Additional Protocols thereto, namely, the Protocol against the Smuggling of Migrants by Land, Sea and Air, and the Protocol to Prevent, Suppress and Punish Trafficking in Persons, Especially Women and Children, and urged States that had not done so to ratify them (par. 33). 
Rights, on The Right to Information on Consular Assistance in the Framework of the Guarantees of the Due Process of Law (1999), and on The Juridical Condition and Rights of the Undocumented Migrants (2003), as well as the Judgments of the International Court of Justice in the LaGrand (2001) and the Avena and Other Mexican Nationals (2004) cases $^{95}$.

At regional level, the Inter-American Commission on Human Rights (IAComHR), pursuant to a request of the General Assembly of the Organization of American States (OAS) ${ }^{96}$, established the mandate of its Special Rapporteur on Migrant Workers and their Families in 1997, with due emphasis on their situation of "special vulnerabilities". From 1997 onwards, the Special Rapporteur has been engaged on the work of monitoring of the situation of migrants and their families in the region, so as to "general awareness" of the States' duty to protect them and "to act promptly" on petitions or communications on their part. The Special Rapporteur has issued recommendations to States, has prepared reports and special studies, and has carried out visits to countries of the region, including the United States, Mexico, Guatemala and Costa Rica. The research topics examined so far, in order "to enhance the awareness" of the adversities faced by migrant workers and their families, include discrimination in general, racism and xenophobia, due process of law, detention conditions, smuggling of migrants and trafficking in persons, migratory practices and their economic consequences ${ }^{97}$.

\section{Social Justice and the Prevention of Forced Migrations: The Legacy of United Nations World Conferences}

A trend of contemporary European legal writing has invoked the doctrine of the international responsibility of the State in order to declare the State practice generating refugees - and displace persons - as constituting a internationally wrongful act (mainly in the presence of the element of culpa lata) ${ }^{98}$. The conceptual basis for this doctrinal construction can be found in the work of the U.N. International Law Commission on the theme of State responsibility99. A justification for this doctrinal elaboration lies in the fact that the international intruments of protection of refugees have limited the provision of obligations only on the part of receiving States, but not in relation to States of origin, of refugees; as from this finding, a customary norm of Humanitarian Law prohibiting the

95 6th. preambular paragraph.

96 OAS, G.A. resolutions AG/RES.1404/XXVI-O/96 (of 1996) and AG/RES.1480/XXVII-0/97 (of 1997).

97 OAS, Special Rapporteurship on Migrant Workers and Their Families, Washington D.C., IAComHR, document www.cidh.oas.org/ migrants, 2007, pp. 1-10.

98 P. Akhavan and M. Bergsmo, "The Application of the Doctrine of State Responsibility to Refugee Creating States”, 58 Nordic Journal of International Law - Acta Scandinavica Juris Gentium (1989) pp. 243-256.

99 Cf. R. Hofmann, "Refugee-Generating Policies and the Law of State Responsibility", 45 Zeitschrift für ausländisches öffentliches Recht und Völkerrecht (1985) pp. 694-713. 
generation of fluxes of refugees is invoked ${ }^{100}$. Therefrom the consequences are established of the internationally wrongful act of generating fluxes of refugees - which would apply a fortiori to sudden migratory fluxes, - also for the effects of reparations.

Such doctrinal endeavours disclose, in my view, both positive and negative aspects. On the one hand, the enlarge the horizon for the examination of the matter, comprising at a time both the receiving State as well as that of origin, and seeking protection of human rights in both. On the other hand, they move on to the ambit of reparations with a private law approach, attempting to justify sanctions to States that are not the only responsible for forced migratory fluxes. In a "globalized" world such as that of our days, full of profound iniquities among and within States, how to identify the origin of so much socio-economic cruelty, how to draw the dividing line, how to single out States (precisely the poorer) responsible for forced migrations, so as to justify sanctions or reprisals?

This, in my understanding, does not appear to be the path to follow. The problem of forced population fluxes ought to be treated as a truly global issue, concerning the international community as a whole. It cannot be properly approached from an outdated and strict bilateral outlook (focusing only on the receiving State and the State of origin) or a merely inter-State perspective. Being a global issue, it brings to the fore the obligations erga omnes of protection of the victimized migrants. The conceptual development of such obligations - and of the juridical consequences of their breach - remains a high priority of contemporary legal science.

Is has been argued that, in face of the contemporary phenomenon of forced migrations, the responsibility of individual States cannot be dissociated from the (subsidiary) responsibility of the international community of States as a whole ${ }^{101}$. As the causes of such forced migrations may, in certain circumstances, amount to gross and massive violations of human rights, a reassessment of the conceptual basis of refuge may lead to a needed and gradual configuration of the right to survival of the affected or endangered segments of the population ${ }^{102}$. More than survival only, what is here at issue is the right to live with dignity ${ }^{103}$.

The whole issue brings to the fore the imperatives of social justice, at universal level. And a special emphasis ought to fall upon the prevention of forced migrations. In this connection, at United Nations level, the system of early

100 W. Czapli_ski and P. Sturma, "La responsabilité des États pour les flux de réfugiés provoqués par eux", 40 Annuaire français de Droit international (1994) pp. 156-169.

101 L. Peral Fernández, Éxodos Masivos, Supervivencia y Mantenimiento de la Paz, Madrid, Ed. Trotta, 2001, pp. 208.

102 Ibid., pp. 72 and 79-81.

103 For general studies, cf. J.G.C. van Aggelen, Le rôle des organisations internationales dans la protection du droit à la vie, Bruxelles, E. Story-Scientia, 1986, pp. 1-89; D. Prémont et alii (eds.), Le droit à la vie quarante ans après l'adoption de la Déclaration Universelle des Droits de l'Homme: Évolution conceptuelle, normative et jurisprudentielle, Genève, CID, 1992, pp. 5-91. 
warning may be recalled: it was born out of a proposal, in the early eighties, by the Special Rapporteur on the question of human rights mass exoduses. Subsequently the theme was related to that of internally displaced persons ${ }^{104}$. In 1997, the U.N. High-Commissioner for Human Rights observed that, in the context of mass exoduses and human rights,

"the term "prevention" is not to be interpreted in the sence of impeding that persons abandon a zone or a country but rather in the sense of impeding that the situation of human rights deteriorates itself to such a point that the abandonment is the only option and also of impeding (...) the deliberate adoption of measures to displace by force great numbers of persons, such as mass expulsions en mass, internal displacements and house eviction, forced resettlement or repatriation" 105 .

Furthermore, the final documents of the recent cycle of World Conferences of the United Nations of the nineties contain additional elements which allow us to approach adequately the issue of population fluxes as a truly global issue, situated in the conceptual universe of human rights ${ }^{106}$. Thus, e.g., the 1993 Vienna Declaration and Programme of Action, adopted by the II World Conference of Human Rights, urged all States to guarantee the protection of human rights of all migrant workers and members of their families (part II, par. 33). The final document of the Vienna Conference further asserted the importance to create conditions that promote greater harmony and tolerance among migrant workers and the rest of the society of the receiving State (par. 34). At last, it urged States to ratify as soon as possible the International Convention on the Protection of the Rights of All Migrant Workers and Members of their Families (par. 35).

The International Conference on Population and Development (Cairo, 1994) approached of course the matter at issue, having called for a global approach to the migratory phenomenon at world level (chapter X of the 1994 Cairo Programme of Action). The Cairo Conference examined the causes of

104 Cf. U.N., document E/CN.4/1995/CRP.1, of 30.01.1995, pp. 1-119.

105 U.N., Derechos Humanos y Éxodos en Masa - Informe del Alto Comisionado para los Derechos Humanos, document E/CN.4/1997/42, of 14.01.1997, p. 4, par. 8, and cf. pp. 4-5, pars. 9-10.

106 For a general account, cf. A.A. Cançado Trindade, "Relations between Sustainable Development and Economic, Social and Cultural Rights: Recent Developments", in International Legal Issues Arising under the United Nations Decade of International Law (eds. N. Al-Nauimi and R. Meese), Deventer, Kluwer, 1995, pp. 1051-1077; A.A. Cançado Trindade, "The Contribution of Recent World Conferences of the United Nations to the Relations between Sustainable Development and Economic, Social and Cultural Rights", in Les hommes et l'environnement: Quels droits pour le vingt-et-unième siècle? - Études en hommage à Alexandre Kiss (eds. M. Prieur and C. Lambrechts), Paris, Éd. Frison-Roche, 1998, pp. 119-146; A.A. Cançado Trindade, "Sustainable Human Development and Conditions of Life as a Matter of Legitimate International Concern: The Legacy of the U.N. World Conferences", in Japan and International Law - Past, Present and Future (International Symposium to Mark the Centennial of the Japanese Association of International Law), The Hague, Kluwer, 1999, pp. 285-309; A.A. Cançado Trindade, Tratado de Direito Internacional dos Direitos Humanos, vol. III, Porto Alegre/Brazil, S.A. Fabris Ed., 2003, pp. 235-299; M.G. Schechter, United Nations Global Conferences, London, Routledge, 2005, pp. 95-100 and 134-139. 
migrations, and urged the adoption of provisions relating to documented and undocumented migrant workers ${ }^{107}$.

One year later, the 1995 Programme of Action of Copenhagen, adopted by the World Summit on Social Development, in approaching the creation of productive employment and reduction of unemployment, warned as to the need of greater attention at national level to the situation of migratory workers and members of their families (chapter III). In approaching the issue of social integration social, it urged the fostering of equality and social justice, widening inter alia basic education, - encompassing also of the children of migrant parents, - and promoting the equitable treatment and integration of documented migratory workers and the members of their families (chapter IV).

The Copenhagen World Summit, moreover, urged States to cooperate "to reduce the causes of undocumented migration" and to safeguard "the fundamental human rights of undocumented migrants, impeding their exploitation" and providing them domestic remedies ${ }^{108}$. It urged, at last, the States to ratify and apply the international instruments concerning migrant workers and the members of their families ${ }^{109}$.

The particular situation of women migrant workers (victimized by violence on the basis of sex) was object of considerable attention of the Part of the IV World Conference on Women (Beijing, 1995). The 1995 Beijing Platform of Action, adopted by the Conference, called upon States to recognize the vulnerability in face of violence and other forms of ill treatment of migrant women, including women migrant workers (chapter IV.D) ${ }^{110}$.

On its turn, the II World Conference on Human Settlements (HabitatII, Istambul, 1996) pointed out the relevant role of human settlements in the realization of human rights, in particular, inter alia, the human right to adequate housing and the right to development. In this respect, the 1996 HabitatII Programme formulated recomendations pertaining to "the legal security of tenancy, the prevention of expulsions, the fostering of refuge centres and of support rendered to basic services and to the units education and health in favour of displaced persons, among other vulnerable groups"111.

Last but not least, the U.N. World Conference against Racism, Racial Discrimination, Xenophobia and Related Intolerance (Dunbar, 2001) also devoted special attention to migrant workers, in particular to the discrimination they suffer. The 2001 Declaration and Programme of Action adopted by the Dunbar Conference

107 For an assessment of the work of the 1994 Cairo Conference on the issue of international migrations, cf., e.g., S. Johnson, The Politics of Population - The International Conference on Population and Development, Cairo 1994, London, Earthscan, 1995, pp. 165-174.

108 U.N./Centre for Human Rights, Los Derechos de los Trabajadores Migratorios (Foll. Inf. n. 24), Geneva, U.N., 1996, pp. 19-20.

109 Ibid., p. 19.

110 Cf. ibid., p. 20.

111 U.N., Derechos Humanos y Éxodos en Masa..., op. cit. supra n. (105), p. 21, par. 61. 
urged States to fight against manifestations of generalized marginalization of migrants, of xenophobia and racist prejudices, thus abiding by their obligations pursuant to international instruments of human rights, irrespective of the situation in which migrants find themselves (pars. 24 and 26).

Recently, the aforementioned resolution 2005/47 (of 04.19.2005) of the former U.N. Commission on Human Rights reaffirmed the provisions concerning the protection of the rights of migrants and their families enshrined into the final documents adopted by the U.N. World Conferences on Human Rights (1993), on Population and Development (1994), on Social Development (1995), on Women (1995), and against Racism, Racial Discrimination, Xenophobia and Related Intolerance (2001) ${ }^{112}$. The Office of the U.N. High Commissioner for Human Rights has also been attentive to some of the aspects of the adversities undergone by migrants and their pressing need of protection ${ }^{113}$.

Onits part, the U.N. Committee on theElimination of RacialDiscrimination (CERD), - supervisory organ of the U.N. Convention on the Elimination of All Forms of Racial Discrimination, - in its general recommendation n. 30, of 2005, warned that "under the Convention, differential treatment based on citizenship or immigration status will constitute discrimination if the criteria for such differentiation, judged in the light of the objectives and purposes of the Convention, are not applied pursuant to a legitimate aim, and are not proportional to the achievement of this aim" (par. 4). The recommendation devotes a whole section (IV) to "access to citizenship" (pars. 13-17), and further addresses the issues of prevention and redress of problems faced by "non-citizen workers" (par. 34), as well as of ensuring "the access of victims to effective legal remedies" and their "right to seek just and adequate reparation" for the wrongs suffered (par. 18).

\section{Final Reflections on the Matter}

As a true global issue, the phenomenon of forced migrations requires greater concertation at universal level to secure the prevalence of the rights of migrants and their families. A relevant role is reserved to public policies, as well as to mobilization of entities of the civil society to mitigate their sufferings and improve their conditions of day-today life. Such entities can, at first, help the organs of assistance and protection in the identification itself of the distinct characteristics assumed by the migratory phenomenon in different countries ${ }^{114}$.

112 4th. preambular paragraph.

113 Cf. U.N., Recommended Principles and Guidelines on Human Rights and Human Trafficking - Report of the U.N. High Commissioner for Human Rights to the Economic and Social Council, U.N document E/2002/68/ Add.1, of 20.05.2002, pp. 3-16.

114 On such distinct characteristics, e.g., in some Latin American countries, cf. IIHR, Balance y Perspectivas del Fenómeno Migratorio en América Latina: Punto de Aproximación desde la Perspectiva de la Protección de los Derechos Humanos, San José of Costa Rica, IIHR, 1998, p. 2 (restricted circulation). 
Secondly, they can denounce situations of flagrant violations of the human rights of migrants ${ }^{115}$.

Thirdly, they can assist in emergency action. Fourthly, they can help to foster the institutional strengthening to face the migratory phenomenon, and to empower the persons affected ${ }^{116}$. And fifthly, by means of the education in human rights, they can help to erradicate xenophobia and other existing prejudices in national societies. Advances in this domain will be achieved, as already pointed out, in an atmosphere of human solidarity. Under this perspective, recent "constructions" of the type of "irregular" - or, worse still, "illegal" - migrants are quite negative ${ }^{117}$, and do not assist at all in seeking durable solutions to the problems faced by migrants worldwide.

Human beings are not deprived of the rights inherent to them as such, as a result of their migratory status or any other circumstance; one can envisage the human rights of the uprooted, and, - contrary to what some would appear to try to make one believe nowadays, - the principle of non-refoulement belongs to the domain of jus cogens ${ }^{118}$. The discretionality of States has its limits, and their policies on deportation and expulsion ought to abide by the imperative norms of international law.

On the positive side, there is nowadays a greater consciousness of the pressing needs of protection of migrants worldwide. The United Nations World Conferences along the nineties and in the passage of the century have contributed decisively to create this new awareness. They have placed due emphasis on the needs of protection of persons and segments of the population in situations of vulnerability. Nowadays, seminars and meetings of non-governmental and governmental experts are convened more and more often, in the search for solutions bearing in mind the imperatives of protection of migrants ${ }^{119}$. Yet, greater concertation at universal level is much needed, as the protection of migrants, in increasing numbers from distinct parts of the world, has become a legitimate concern of the international community as a whole.

It is reassuring that the 2000 United Nations Millenium Declaration was attentive enought to include (par. 25) a call:

115 Cf., e.g., J.E. Méndez, A Proposal for Action on Sudden Forced Migrations, San José of Costa Rica, IIHR, 1997, p. 10 (restricted circulation).

116 Cf. IIHR, Papel Actual de las Organizaciones de la Sociedad Civil en Su Trabajo con las Poblaciones Migrantes en el Continente, San José of Costa Rica, IIHR, 1998, pp. 1-14 (restricted circulation).

117 L. Ortiz Ahlf, "Derechos Humanos de los Migrantes", 35 Jurídica - Anuario del Departamento de Derecho de la Universidad Iberoamericana (2005) pp. 14, 19, 23 and 26-29.

118 A.A. Cançado Trindade, "El Desarraigo como Problema de Derechos Humanos frente a la Conciencia Jurídica Universal", in Movimientos de Personas e Ideas y Multiculturalidad (Forum Deusto), vol. I, Bilbao, University of Deusto, 2003, pp. 87-103.

119 Cf., e.g., among many other initiatives: International Institute of Humanitarian Law (IIHL), Conflict Prevention - The Humanitarian Perspective (Proceedings, August/September 1994), San Remo, IIHL, 1994, pp. 7-185; Universidad de Sevilla, La Asistencia Humanitaria en el Derecho Internacional Contemporáneo, Sevilla, Univ. de Sevilla, 1997, pp. 1-74 (internal circulation); XVI Cumbre Iberoamericana, Compromiso de Montevideo sobre Migraciones y Desarrollo, of 05.11.2006, pp. 1-10 (internal circulation). 
"to take measures to ensure respect for and protection of the human rights of migrants, migrant workers and their families, to eliminate the increasing acts of racism and xenophobia in many societies and to promote greater harmony and tolerance in all societies".

Half a decade later, in September 2005, the U.N. document 2005 World Summit Outcome, also in a reassuring way, enlarged the express reference to the issue of migrations (pars. 61-63), relating migration to development (par. 61), and reaffirming "our resolve to take measures to ensure respect for and protection of the human rights of migrants, migrant workers and members of their families" (par. 62).

Advances in this domain, however, will only be achieved amidst a radical change of mentality, and a greater consciousness of the pressing needs to protect the basic rights of migrants. In any scale of values, considerations of a humanitarian order ought to prevail over those of an economic or financial order, over the alleged "protectionism" of the "work market", over group rivalries. There is, definitively, a pressing need to situate the human beings in the place that corresponds to him, certainly above capitals, goods and services. This is one of the major challenges of the "globalized" world wherein we live, from the perspective of human rights.

May I conclude this article by reasserting what I have sustained, two years ago, in my General Course on Public International Law, delivered at the Hague Academy of International Law, to the effect that, in my understanding, advances in Law are ultimately due to human conscience, the ultimate material source of all $\mathrm{Law}^{120}$. It took many centuries for human beings to become aware of the problem of time, for them to acquire a "historical conscience"121. And, since the heroic times of The Iliad of Homer in ancient Greece, it took a few more centuries for human beings to acquire an "ethical conscience", that is, to realize that they were responsible for their own conduct (each one being the inner "judge" of his own conduct) and for the way they treated others, their fellow human beings.

In this connection, in the XXVIII Immanuel Kant used to conceptualize "conscience" as the "internal tribunal" of each person as a "moral being" 122. Centuries earlier, the emergence of human conscience helped to face with some reason the so-called "struggle for existence" 123 , the old struggle for survival. The recta ratio present in the writings of the so-called "founding fathers" of the Law of Nations in the XVI and XVII centuries (such as F. de Vitoria, F. Suárez, H. Grotius, among others), in envisaging the civitas maxima gentium, in supporting

120 A.A. Cançado Trindade, "International Law for Humankind: Towards a New Jus Gentium - General Course on Public International Law - Part I", 316 Recueil des Cours de l'Académie de Droit International de la Haye (2005) pp. 177-202.

121 Ernst Cassirer, Essai sur l'homme, Paris, Éd. de Minuit, 1975, pp. 243-244.

122 Particularly in his Fondements de la métaphysique des moeurs (1785); an cf. I. Kant, [Critique de] la raison pratique, Paris, PUF, 1963 [reed.], p. 201.

123 Karl Popper, In Search of a Better World, London, Routledge, 2000 [reprint], p. 28. 
the jus communications worldwide, and in propounding the essential unity of the humankind, - such recta ratio of scholastic thinking and writing, had its roots going back to the ancient Greeks (Plato and Aristotle), corresponding to their orthos logos 124 .

It is human conscience which best governs the relations among human beings, whether inter-individually or in groups. It is the universal juridical conscience that guides universal international law, as its ultimate material source ${ }^{125}$, that moves it forward, to respond to changing needs of protection of the human person and to fulfil the basic aim of the realization of justice.

Recebido em 15 de outubro de 2007

Aprovado em 15 de maio de 2008

\section{Resumo}

O artigo visa demonstrar a evolução do direito internacional em relação à questão dos direitos dos migrantes forçados. O autor apóia-se em diversos textos, casos e resoluções do meio regional, através das cortes interamericana e européia, e do meio global, através da Corte Internacional. É apresentada a evolução que ocorreu no direito internacional na virada do milênio que reconhece os direitos dos migrantes. No entanto, é sublinhada a necessidade do desenvolvimento dessas normas em relação ao tema e do reconhecimento, da parte dos Estados, da importância das leis que visam assegurar o respeito aos direitos humanos relativos aos migrantes e suas famílias.

\section{Abstract}

The article attempt to demonstrate the evolution of international law in connected to the subject of the forced immigrants'. The author supported by several texts, cases and resolutions of the regional level, through interamerican court and European court, and the global level, through the international court. It's shown the evolution that occurred in international law in millennium turn over, which recognize the immigrants' rights. However, it's stressed the necessity of the development of those laws connected to the theme e the recognition, from the States; the importance of law's that effort to ensure the respect to human rights relative to the immigrants and their families.

Palavras-chave: direito internacional, direitos humanos, migração.

Keywords: international law, human rights, migration.

124 A.A. Cançado Trindade, "International Law for Humankind: Towards a New Jus Gentium...”, op. cit. supra n. (120), Part I, pp. 40-42 and 179-184.

125 Ibid., pp. 177-202. 